\title{
Renovation need for apartment buildings in Latvia
}

\section{Необходимость реновации жилых зданий в Латвии}

\author{
A. Borodinecs, \\ J. Zemitis, \\ J Sorokins, \\ Riga Technical University, Riga, Latvia \\ D.V. Baranova, \\ D.O. Sovetnikov, \\ Peter the Great St. Petersburg Polytechnic \\ University, St. Petersburg, Russia
}

Key words: Latvian building stock; apartment buildings; energy efficiency; energy audit; ventilation

\author{
д-р техн. наук, профессор \\ А.Б. Бородинец, \\ д-р техн. наук, доцент ю. Земитис, \\ M.Sc., докторант Ю. Сорокинс, \\ Рижский технический университет, г. Рига, \\ Латвия \\ студент Д.В. Баранова, \\ студент Д.О. Советников, \\ Санкт-Петербургский политехнический \\ университет Петра Великого, г. Санкт- \\ Петербург, Россия
}

\begin{abstract}
Ключевые слова: жилищный фонд Латвии; многоквартирные здания; энергетическая эфффективность, энергетический аудит, вентиляция
\end{abstract}

Abstract. Residential buildings in Latvia are one of the essential heat consumers during the heating season. The majority of Latvian as well as European residential buildings were constructed within the period from 1965 to 1990. Introduction presents brief overview of current situation in Latvian and EU countries. This chapter provides overview of real energy consumption and definition of buildings technical conditions. Materials and methods are based on evaluation of standardized energy consumption in two kindergartens and multi apartment buildings including also dynamic energy simulation. Chapter on thermal performance of building envelope provides an extensive comparison of heat transfer coefficients in non-renovated buildings as well as comparison with normative values. Section on energy consumption of existing multi apartment buildings presents review of buildings real energy consumption before and after renovation. In addition this chapter evaluated indoor air quality. This study was done in order to define necessary reconstruction goals to reach European Regional Development Fund project "A New Concept for Sustainable and Nearly Zero-Energy Buildings" Nr. 1.1.1.1/16/A/007 main targets.

Аннотация. Жилые здания в Латвии являются одним из основных потребителей тепла в отопительный сезон. Большинство латвийских и европейских жилых зданий были построены в период с 1965 по 1990 год. Введение представляет краткий обзор текущей ситуации в Латвии и странах ЕС. В этой главе представлен обзор реального потребления энергии и определение технических условий для зданий. Материалы и методы основаны на оценке стандартизированного потребления энергии в двух детских садах и многоквартирных домах, включая также динамическое моделирование энергии. В главе, касающейся тепловых характеристик ограждающих конструкций зданий, дано подробное сравнение коэффрициентов теплоотдачи в не отреставрированных зданиях и сравнение их с нормативными значениями. В разделе об энергопотреблении существующих многоквартирных домов представлен обзор реального потребления энергии зданиями до и после модернизации. Кроме того, в этой главе дается оценка качества воздуха в помещении.

\section{Introduction}

Residential buildings in Latvia are one of the essential heat consumers during the heating season. In 2008 the residential sector in Latvia has consumed $74 \%$ of all amount of produced heating energy. The majority of residential buildings were constructed within the period from 1965 to 1990. The importance of urgent need for renovation of existing building stock was highline in several independent studies $[1,2]$. These studies evaluated complex approach for retrofitting of multi apartment buildings with a focus on sustainable development at district and national level, similar to research $[3,8]$ data. It should be mentioned that renovation of existing building stock became an actual problem in EU and other countries as well [6, 9, 12]. In general, existing building stock i classified as post II word war, before II 
word war and modern building stock build after mid1990ies. It is vitally important to make proper classification of building stock in order to choose most optimal and cost efficient renovation solution. The building built before II word has a completely different construction solution and technical conditions which require more detailed and specific selection of renovation package [14, 21]. This study is focused on analysis post II word war building stock as most cruitial energy consumer. Application of renovation packages can provide a significant reduction of energy consumption by existing building stock $(10,16$, 17).

According to the data of Statistical Bureau of Latvia, the residential building construction may be subdivided in the following basic categories:

-Pre-war construction (till 1945);

-Post-war construction (from 1945 to 1991);

-New construction (from 1991);

Number of dwelling according to construction period is shown in Table 1.

Table 1 Number of dwelling according to construction period

\begin{tabular}{|c|c|c|c|c|}
\hline $\begin{array}{c}\text { Year of } \\
\text { construction }\end{array}$ & $\begin{array}{c}\text { Single family } \\
\text { houses }\end{array}$ & $\begin{array}{c}\text { Two apartments } \\
\text { houses }\end{array}$ & $\begin{array}{c}\text { Terraced } \\
\text { house }\end{array}$ & $\begin{array}{c}\text { Multi apartment } \\
\text { buildings }\end{array}$ \\
\hline$<1945$ & 97737 & 3406 & 2278 & 120218 \\
\hline $1945-1960$ & 38047 & 2503 & 912 & 49248 \\
\hline $1961-1970$ & 26152 & 1081 & 536 & 141169 \\
\hline $1971-1980$ & 27018 & 1081 & 677 & 180749 \\
\hline $1981-1990$ & 35856 & 563 & 340 & 162723 \\
\hline$>1991(2011)$ & 43846 & 1826 & 1509 & 51268 \\
\hline
\end{tabular}

According to the Table 1 data, share of multi apartment buildings constructed between 1945 and 1990 is is $54 \%$ of total number of dwelling buildings. During the pre-war period mainly capital brick buildings and low-storey wooden buildings were built. Both furnace heating and central heating systems were used to heat buildings. In subsequent years these buildings have been gradually connected to the central heating system. It should be noted that unfortunately the majority of these buildings are in a bad technical condition at present.

From 1945 to 1991 mainly typical multi apartment buildings were constructed. Types of buildings 103, 316 and 467 series were among the most widespread. There are approximately 38933 multi apartment buildings in Latvia. The standard thermal conductivity for exterior brick walls was in average $1.33 \mathrm{~W} /\left(\mathrm{m}^{2} \cdot \mathrm{K}\right)$ and for exterior expanded-clay concrete walls $-1.20 \mathrm{~W} /\left(\mathrm{m}^{2} \cdot \mathrm{K}\right)$, which is at least 3.5 times higher than the values specified in the current Latvian Building Code LBN 002-15 "Thermal performance of building envelope" [3] which is valid in Latvia. The largest part of residential buildings (89\%) is privately owned, $11 \%$ belong to the state and self-governments and $2 \%$ belong to apartment cooperatives. The residential building stock of Latvia is represented mainly by one and two-room apartments.

The common problems for existing building stock include non-insulated or partly insulated heating and hot water piping systems, poor thermal properties of building envelope as well as balancing problems due to applied one-pipe heating system. In addition, the heating elements don't have individual regulation possibilities that cause overheating in kindergartens where temperature reduction by window opening is limited.

The average annual specific heat consumption for space heating of Latvian dwelling buildings is $104.40 \mathrm{kWh} / \mathrm{m}^{2}$ and for hot water supply $-73.30 \mathrm{kWh} / \mathrm{m}^{2}$ [2]. The main source of heating in Latvia is provided by district heat supply systems. Totally about $65 \%$ of the housing stock is connected to district heating. The specific heating energy consumption in Latvian kindergartens is estimated to vary between 196 and $285 \mathrm{kWh} / \mathrm{m}^{2}$. Therefore to reduce energy consumption to meet the municipality's goal of $100 \mathrm{kWh} / \mathrm{m}^{2}$, even further actions should be taken, e.g. including, education of kindergarten personnel, HVAC system retrofit and use of high-efficiency HVAC equipment. Almost all renovated building can be found on on-line map.

Map provides also short description of implemented measures and expected energy reduction. The total number of already renovated multi storey buildings in Latvia had reached 711 as on year 2016 .

Бородинец А., Земитис Ю., Сорокинс Ю., Баранова Д.В. Советников Д.О. Необходимость реновации жилых зданий в Латвии // Инженерно-строительный журнал. 2016. № 8(68). С. 58-64. 
These numbers show the high interest in refurbishment process which is stimulated by the possibility to attract European funds.

\section{Materials and methods}

Evaluation of existing multi apartment buildings energy efficiency is based on analysis of real measured data on heat consumption and theoretical calculations using IDA-ICE and RISUKA.

The existing buildings' energy certification scheme is based on unique rating criteria standardized annual specific heat consumption, which is calculated on the basis of real measured heat consumption for space heating and hot water supply.

The measured heat consumption was recalculated to standardized annual specific heat consumption:

$$
q_{s t}=\frac{q_{h} D D_{s t}}{D D}, k W h / m^{2}
$$

where: A - heated built-in area, $\mathrm{m}^{2}$; DD - degree-days of heating period in rating year; DDst - degreedays of standard year in favorable economic conditions; qs.h. - measured consumption in analyzed year, $\mathrm{kWh} / \mathrm{m}^{2}$ year.

Degree day is widely used to evaluate energy consumptions under different climatic condition [20]. The chosen cases include two kindergartens and multiapartment buildings. The renovation package for both kindergartens as well as for residential building included similar improvements to building facades, as well as heating and ventilation systems. In all cases facades were insulated with additional $100 \mathrm{~mm}$ of insulation, also the windows were changed to double glazed PVC windows, additional insulation on pipelines was placed, the radiators were replaced and system was rebalanced. The old one-pipe heating systems with old cast iron heating elements were completely replaced with two-pipe newly built heating system with panel type radiators equipped with thermostatic valves.

\section{Thermal performance of building envelope}

In Latvia, the greatest part of residential buildings falls on series 103,316 and 467 , the total space of which is 16801 thousand $\mathrm{m}^{2}$. The standard heat transfer coefficients for exterior brick walls was in average $1.33 \mathrm{~W} /\left(\mathrm{m}^{2} \cdot \mathrm{K}\right)$ and for exterior expanded-clay concrete walls $-1.20 \mathrm{~W} /\left(\mathrm{m}^{2} \cdot \mathrm{K}\right)$, which is at least 4.5 times higher than the values specified in the current Latvian Building Code LBN 002-15 "Thermal performance of building envelope" which is valid in Latvia [11].

Despite of the fact that buildings of various types differ visually, the internal engineering and technical structure of all buildings is practically the same in all types of buildings.

Till 1960 mainly calcium-silicate brick buildings were constructed, but at the end of 1960 they started to construct panel buildings. Practically all buildings were connected to the territorial centralized heating system.

The comparison of existing heat transfer coefficient and normative values for common multi apartment building in Latvia is shown in Table 2 . 
Table 2. The comparison of existing heat transfer coefficient and normative values for common multi apartment building in Latvia

\begin{tabular}{|c|c|c|}
\hline Project type & Type of envelope & Ureal, $\mathbf{W} / \mathbf{m}^{2} \mathbf{K}$ \\
\hline \multirow{4}{*}{103} & Roof & 0.75 \\
\cline { 2 - 3 } & Aerated concrete panel wall & 0.89 \\
\cline { 2 - 3 } & Brick wall & 1.27 \\
\cline { 2 - 3 } & Basement ceilings & 1.03 \\
\cline { 2 - 3 } & Window & 2.56 \\
\cline { 2 - 3 } & Attic ceiling & 1.46 \\
\cline { 2 - 3 } & Brick wall (1) & 1.25 \\
\cline { 2 - 3 } & Brick wall (2) & 1.32 \\
\cline { 2 - 3 } & Basement ceilings & 1.16 \\
\hline \multirow{4}{*}{464} & Window & 2.56 \\
\cline { 2 - 3 } & Externalexpandedclay aggregate panels & 0.81 \\
\cline { 2 - 3 } & Basement ceilings & 1.48 \\
\cline { 2 - 3 } & Window & 1.33 \\
\hline \multirow{4}{*}{$467 / 5$} & Attic ceiling & 2.56 \\
\cline { 2 - 3 } & Expanded clay aggregate panel wall & 1.54 \\
\cline { 2 - 3 } & Basement ceilings & 1.48 \\
\cline { 2 - 3 } & Window & 1.49 \\
\hline \multirow{4}{*}{$602 / 9$} & Attic ceiling & 2.56 \\
\cline { 2 - 3 } & Expanded clay aggregate panel wall & 0.8 \\
\cline { 2 - 3 } & Basement ceilings & 1.48 \\
\cline { 2 - 3 } & Window & 1.14 \\
\hline \multirow{4}{*}{} & & 2.56 \\
\hline
\end{tabular}

Comparison of U-value for residential buildings in Latvia is shown in Figure 1.

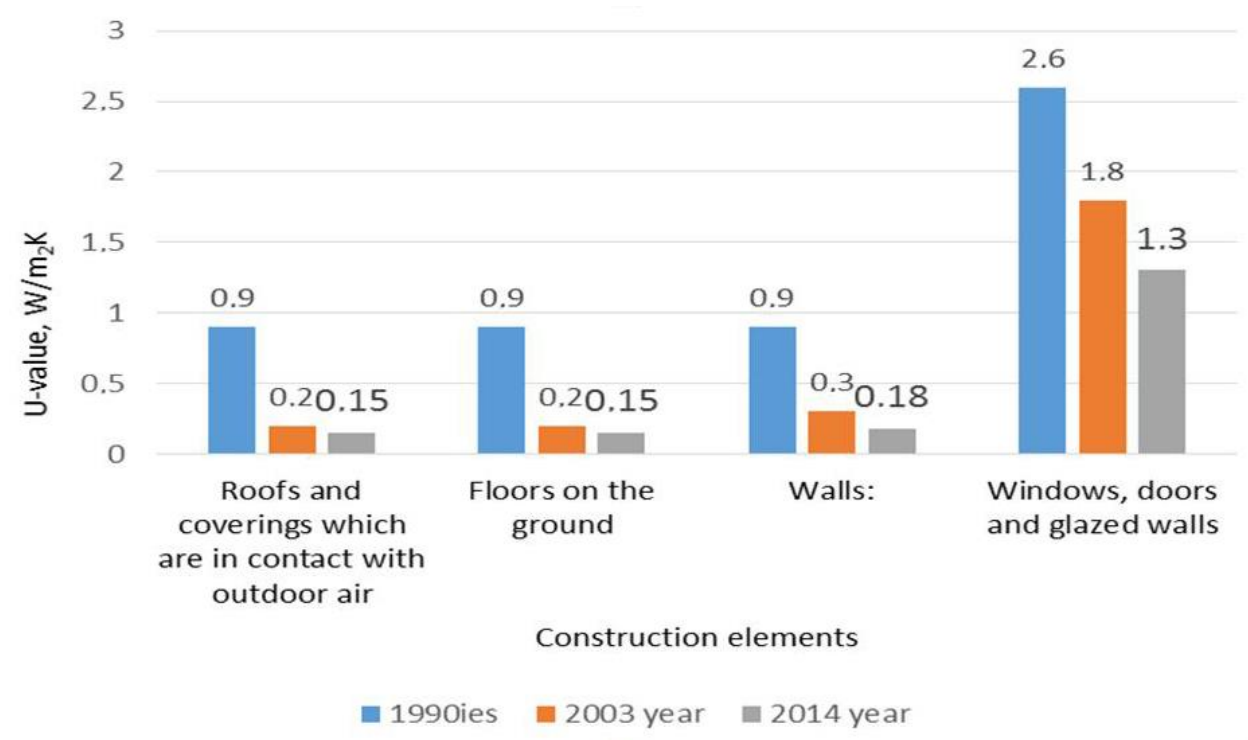

Figure 1. U-value for residential buildings in Latvia

\section{Energy consumption of existing multi apartment buildings}

To evaluate the impact of renovation measurements of consumed energy for heating have been performed and comparison to the predicted ones has been made. The Table 3 shows how these results stack up.

Бородинец А., Земитис Ю., Сорокинс Ю., Баранова Д.В. Советников Д.О. Необходимость реновации жилых зданий в Латвии // Инженерно-строительный журнал. 2016. № 8(68). С. 58-64. 
Table 3. Comparison of heat consumption before renovation with theoretically predicted and measured heat consumption in Latvia

\begin{tabular}{|c|c|c|c|}
\hline \multirow{2}{*}{ Objects } & \multicolumn{3}{|c|}{ Heat consumption } \\
\cline { 3 - 4 } & \multirow{2}{*}{ Non-renovated } & \multicolumn{2}{|c|}{ After renovation } \\
\cline { 3 - 4 } & & Theoretical estimation & Real measured \\
\hline \multirow{2}{*}{ Kindergarten } & $227 \mathrm{kWh} / \mathrm{m}^{2}$ & $121 \mathrm{kWh} / \mathrm{m}^{2}$ & $150 \mathrm{kWh} / \mathrm{m}^{2}$ \\
& $(30.5 \mathrm{tCO}$ & $(17.3 \mathrm{tCO}$ & $\left(21.8 \mathrm{t} / \mathrm{CO}_{2}\right)$ \\
\hline \multirow{2}{*}{ Kindergarten } & $245 \mathrm{kWh} / \mathrm{m}^{2}$ & $117 \mathrm{kWh} / \mathrm{m}^{2}$ & $145 \mathrm{kWh} / \mathrm{m}^{2}$ \\
& $(89.3 \mathrm{kgCO} 2)$ & $(58.3 \mathrm{tCO} 2)$ & $\left(71.9 \mathrm{t} / \mathrm{CO}_{2}\right)$ \\
\hline Residential & $150 \mathrm{kWh} / \mathrm{m}^{2}$ & $78 \mathrm{kWh} / \mathrm{m}^{2}$ & $75 \mathrm{kWh} / \mathrm{m}^{2}$ \\
building & $(89.3 \mathrm{kgCO} 2)$ & $\left(54.5 \mathrm{t} / \mathrm{CO}_{2}\right)$ & $\left(44.6 \mathrm{t} / \mathrm{CO}_{2}\right)$ \\
\hline
\end{tabular}

As seen from the Table 3 there are some differences between predicted and measured energy consumptions and mostly the actual measured heat consumption is higher than predicted one. This can be explained by reason that the indoor temperature had risen after renovation. In most cases, this can be considered as a good thing because the indoor temperature before the renovation was too low and by increasing it the indoor climate quality is improved. However, if the temperature rise is unwanted the heating system needs to be rebalanced after the renovation or automation for heating boiler must be installed.

The research $[5,19]$ had shown unsatisfactory indoor air parameters in partly renovated and nonrenovated buildings. The main reason for high level of $\mathrm{CO}_{2}$ emission is lack of air exchange and absence of any ventilation systems. Figure 2 presents comparison of real measured $\mathrm{CO}_{2}$ concentration under different ventilation scenarios in bedroom occupied by two adults.

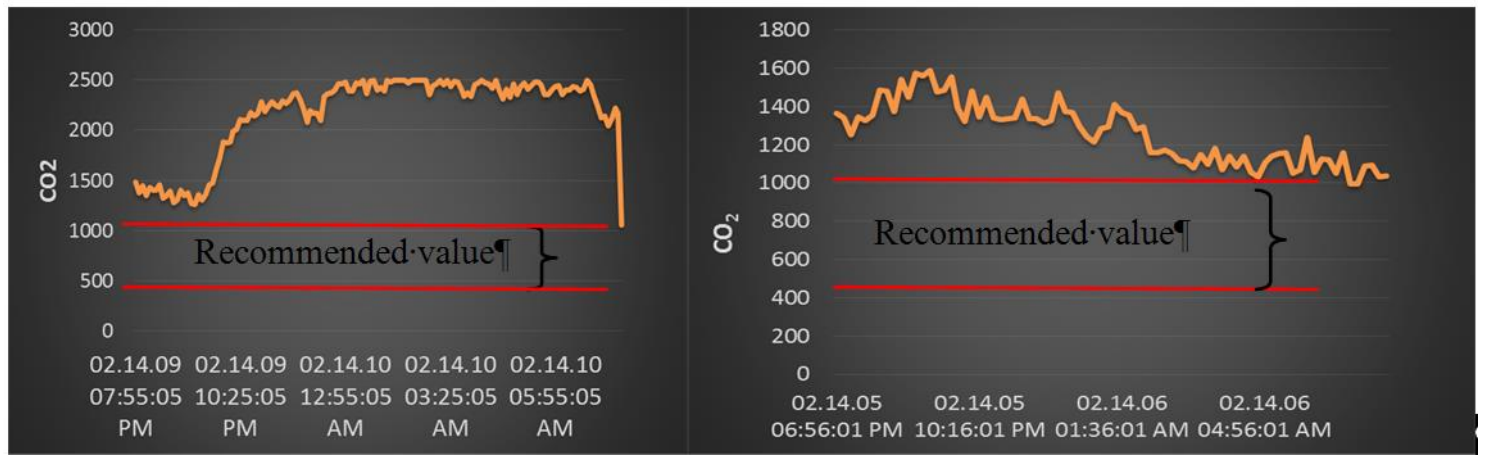

a) without supply/exaust ventialtion

b) with supply/exaust ventialtion

Figure 2. presents comparison of real measured $\mathrm{CO}_{2}$ concentration under different ventilation scenarios

As it can be seen form above-mentioned figure, the especial attention should be paid to proper design of ventilation systems.

According to the STEP-UP [http://stepupsmartcities.eu/] project data, since 2012, each building in City of Riga with a heat substation has been equipped with telemetering system enabling remote heat consumption measurements to be taken. Other data, such as cold and hot water as well as electricity, can be read in accordance with the client's needs. The project implementation was financed by the Riga utility company Riga Siltums through its own capital and loan mechanism. The upgraded meters introduction cost approximately $2.45 \mathrm{~m}$ Euro. It now takes less than three hours to take readings from more than 8,000 substations, saving staff time and ensuring greater data and billing accuracy. The new measures ensure any issues are more quickly resolved and risks identified promptly.

Nowadays energy performance of postwar construction is actual not only in former soviet countries $[7,15]$, but also in European countries [7, 8]. The new innovative technologies should be implemented in new construction as well as in retrofitting of existing buildings. Of the latest studies [4] have shown benefits of latent heat storage in Latvian climatic conditions. Application of latent thermal storage allows reduction of peak loads and wider application of solar energy. According to the study [13] data, optimization of heat consumption and peak loads allows significant saving in district heating systems. Thus overall negative environmental impact is minimizing.

Borodinecs A., Zemitis J., Sorokins J., Baranova D.V., Sovetnikov D.O. Renovation need for apartment buildings in Latvia. Magazine of Civil Engineering. 2016. No. 8. Pp. 58-64. doi: 10.5862/MCE.68.6 


\section{Conclusions}

There are approximately 38933 multi apartment buildings in Latvia. Until February of year 2013 the total number of already renovated multi storey buildings in Latvia had reached 156 or only $0.4 \%$.

The heat consumption after applying thermal insulation during refurbishment process of buildings can be realistically reduced down to $70 \mathrm{kWh} / \mathrm{m}^{2}$ in typical Latvian climate conditions. While nZEB approach requires reduction of thermal energy consumption up to $15-40 \mathrm{kWh} / \mathrm{m}^{2}$ in Latvian climatic conditions.

The optimal U-values of walls after thermal insulations is $0.18-0.22 \mathrm{~W} /\left(\mathrm{m}^{2} \cdot \mathrm{K}\right)$, while for roofs $0.13-$ $0.15 \mathrm{~W} /\left(\mathrm{m}^{2} \cdot \mathrm{K}\right)$.

Due to ventilation systems usually are not renovated, the IAQ measurements in renovated buildings have shown unsatisfactory situation with increased $\mathrm{CO}_{2}$ concentration and high relative humidity.

The nZEB solution should include complex retrofitting measures as well as installation of energy storage, renewable energy sources and exhaust air heat recovery.

\section{Acknowledgements}

This study was supported and financed by European Regional Development Fund project "A New Concept for Sustainable and Nearly Zero-Energy Buildings" Nr. 1.1.1.1/16/A/007.

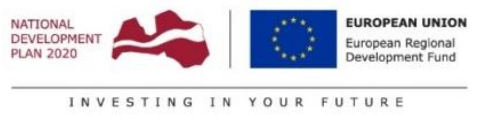

\section{References}

1. Actina G., Geipele I., Zeltins N. Planning and managing problems of energy and energy efficiency at regional and district level in Latvia: Case study. IEOM 2015. Proceedings of 5th International Conference on Industrial Engineering and Operations Management. 2016. P. 7

2. Actina G., Geipele I., Zeltins N. Role of building thermal inertia as a selection criterion of edifice renovation strategy and energy plan development in Latvia: Case study. Proceedings of the 2014 3rd International Conference on Frontier of Energy and Environment Engineering, ICFEEE. 2014. Pp. 361-365.

3. Adeyemi A., Martin D., Kasim R. Improvement of existing buildings for sustainability as against maintenance and rebuild. Proceedings of the 25th International Business Information Management Association Conference Innovation Vision 2020: From Regional Development Sustainability to Global Economic Growth, IBIMA. 2015. Pp. 3527-3537.

4. Bajare D., Kazjonovs J., Korjakins A. Development of latent heat storage phase change material containing plaster. Medziagotyra. 2016. No. 1(22). Pp. 94-97.

5. Borodinecs A., Dzelzitis E., Kreslins A. General requirements for the energy performance of buildings in Latvia. Proceeding of 9th REHVA World Congress "WellBeing Indoors - Clima 2007". Helsinki, Finland. 2007. $7 \mathrm{p}$.

6. Borodinecs A., Zemitis J., Rodriguez-Gabrie A. et al. Handbook on Building Renovation in Central Baltic Region. Riga: Riga Technical University, 2013. 92 p.

7. Gorshkov A., Vatin N., Nemova D., Shabaldin A., Melnikova L., Kirill P. Using life-cycle analysis to assess energy savings delivered by building insulation. Procedia Engineering. 2015. No. 1(117). Pp. 1085-1094.

8. Kauskale L., Geipele I., Zeltins N., Lecis I. Energy aspects of green buildings - international experience. Latvian Journal of Physics and Technical Sciences. No. 6(53). Pp. 21-28.

9. Korniyenko S.V., Vatin N.I., Gorshkov A.S. Thermophysical field testing of residential buildings made of autoclaved aerated concrete blocks. Magazine of Civil

\section{Литература}

1. Actina G., Geipele I., Zeltins N. Planning and managing problems of energy and energy efficiency at regional and district level in Latvia: Case study. IEOM 2015 // Proceedings of 5th International Conference on Industrial Engineering and Operations Management. 2016. P. 7.

2. Actina G., Geipele I., Zeltins N. Role of building thermal inertia as a selection criterion of edifice renovation strategy and energy plan development in Latvia: Case study // Proceedings of the 2014 3rd International Conference on Frontier of Energy and Environment Engineering, ICFEEE. 2014. Pp. 361-365.

3. Adeyemi A., Martin D., Kasim R. Improvement of existing buildings for sustainability as against maintenance and rebuild // Proceedings of the 25th International Business Information Management Association Conference Innovation Vision 2020: From Regional Development Sustainability to Global Economic Growth, IBIMA. 2015. Pp. 3527-3537.

4. Bajare D., Kazjonovs J., Korjakins A. Development of latent heat storage phase change material containing plaster // Medziagotyra. 2016. No. 1(22). Pp. 94-97.

5. Borodinecs A., Dzelzitis E., Kreslins A. General requirements for the energy performance of buildings in Latvia. Proceeding of 9th REHVA World Congress "WellBeing Indoors - Clima 2007". Helsinki, Finland. 2007. 7 p.

6. Borodinecs A., Zemitis J., Rodriguez-Gabrie A. et al. Handbook on Building Renovation in Central Baltic Region. Riga: Riga Technical University, 2013. 92 p.

7. Gorshkov A., Vatin N., Nemova D., Shabaldin A., Melnikova L., Kirill P. Using life-cycle analysis to assess energy savings delivered by building insulation // Procedia Engineering. 2015. № 1(117). Pp. 1085-1094.

8. Kauskale L., Geipele I., Zeltins N., Lecis I. Energy aspects of green buildings - international experience // Latvian Journal of Physics and Technical Sciences. № 6(53). Pp. 21-28.

9. Korniyenko S.V., Vatin N.I., Gorshkov A.S. Thermophysical field testing of residential buildings made of autoclaved aerated concrete blocks // Инженерно-

Бородинец А., Земитис Ю., Сорокинс Ю., Баранова Д.В. Советников Д.О. Необходимость реновации жилых зданий в Латвии // Инженерно-строительный журнал. 2016. № 8(68). С. 58-64. 
Engineering. 2016. №. 4(64). Pp. 10-25.

10. Kuusk K., Kalamees T. Retrofit cost-effectiveness: Estonian apartment buildings. Building Research and Information. 2016. No. 8(44). Pp. 920-934.

11. Latvian Building Code 001-15 "Thermal performance of building envelope".

12. Li J., Ng S.T., Skitmore M. Review of low-carbon refurbishment solutions for residential buildings with particular reference to multi-story buildings in Hong Kong. Renewable and Sustainable Energy Reviews. 2017. No. 73. Pp. 393-407.

13. Magyar Z., Garbai L., Jasper A. Risk-based determination of heat demand for central and district heating by a probability theory approach. Energy and Buildings. 2016. No. 110. Pp. 387-395.

14. Muraj I. Energy efficiency upgrades: Residential buildings from the period UP TO 1940 in Zagreb. International Journal for Housing Science and its Applications. 2016. No. 3(40). Pp. 147-157.

15. Nefedova A., Bykova A., Kosov J., Petrichenko S. Selection of individual automatic heat supply unit of ecomatic LLC. Procedia Engineering. 2015. No. 1(117) Pp. 1102-1111.

16. Ruparathna R., Hewage K., Sadiq R. Economic evaluation of building energy retrofits: A fuzzy based approach. Energy and Buildings. 2017. No. 139. Pp. 395-406.

17. Serghides D.K., Dimitriou S., Katafygiotou M.C., Michaelidou M. Energy efficient refurbishment towards nearly zero energy houses, for the mediterranean region. Energy Procedia. 2015. No. 83. Pp. 533-543.

18. Shipkovs P., Snegirjovs A., Kaskarova G., Shipkovs J. Potential of solar cooling in Latvian conditions. Energy Procedia. 2014. No. 57. Pp. 2629-2635.

19. Stankeviča G, Lešinskis A. Indoor air quality and thermal comfort evaluation in Latvian daycare centers with carbon dioxide, temperature and humidity as indicators Journal of Civil Engineering and Architecture. 2008. No. 2. Pp. 633638.

20. Verbai Z., Lakatos A., Kalmár F. Prediction of energy demand for heating of residential buildings using variable degree day. Energy. 2014. No. 76. Pp. 780-787.

21. Zagorskas J., Burinskienè M., Paliulis G.M., Venckauskaitè J. Innovative solutions for energetic refurbishment of historic brick buildings. Springer Proceedings in Physics. 2014. No. 155. Pp. 477-482.

Anatolijs Borodinecs, +37126079655; anatolijs.borodinecs@rtu.Iv

Jurgis Zemitis, +37128369940; jurgis@iag.Iv

Juris Sorokins,

+37129969420; juris.sorokins@gmail.com

Daria Baranova, +7(921)6401200; baranova-d@mail.ru

Daniil Sovetnikov, +7(911)9019058; sovetnikov.daniil@gmail.com строительный журнал. 2016. № 4(64). Рp. 10-25.

10. Kuusk K., Kalamees T. Retrofit cost-effectiveness: Estonian apartment buildings // Building Research and Information. 2016. № 8(44). Pp. 920-934.

11. Latvian Building Code 001-15 "Thermal performance of building envelope".

12. Li J., Ng S.T., Skitmore M. Review of low-carbon refurbishment solutions for residential buildings with particular reference to multi-story buildings in Hong Kong // Renewable and Sustainable Energy Reviews. 2017. № 73. Pp. 393-407.

13. Magyar Z., Garbai L., Jasper A. Risk-based determination of heat demand for central and district heating by a probability theory approach // Energy and Buildings. 2016. № 110. Pp. 387-395.

14. Muraj I. Energy efficiency upgrades: Residential buildings from the period UP TO 1940 in Zagreb // International Journal for Housing Science and its Applications. 2016. № 3(40). Pp. 147-157.

15. Nefedova A., Bykova A., Kosov J., Petrichenko S. Selection of individual automatic heat supply unit of ecomatic LLC // Procedia Engineering. 2015. № 1(117). Pp. 1102-1111.

16. Ruparathna R., Hewage K., Sadiq R. Economic evaluation of building energy retrofits: A fuzzy based approach // Energy and Buildings. 2017. № 139. Pp. 395-406.

17. Serghides D.K., Dimitriou S., Katafygiotou M.C., Michaelidou M. Energy efficient refurbishment towards nearly zero energy houses, for the mediterranean region // Energy Procedia. 2015. № 83. Pp. 533-543.

18. Shipkovs P., Snegirjovs A., Kaskarova G., Shipkovs J. Potential of solar cooling in Latvian conditions // Energy Procedia. 2014. № 57. Pp. 2629-2635.

19. Stankeviča $G$, Lešinskis $A$. Indoor air quality and therma comfort evaluation in Latvian daycare centers with carbon dioxide, temperature and humidity as indicators // Journal of Civil Engineering and Architecture. 2008. № 2. Pp. 633-638.

20. Verbai Z., Lakatos A., Kalmár F. Prediction of energy demand for heating of residential buildings using variable degree day // Energy. 2014. № 76. Pp. 780-787.

21. Zagorskas J., Burinskienè M., Paliulis G.M., Venckauskaitè J. Innovative solutions for energetic refurbishment of historic brick buildings // Springer Proceedings in Physics. 2014. № 155. Pp. 477-482.

Анатолий Бородинец, +37126079655;

эл. почта: anatolijs.borodinecs@rtu.Iv

Юргис Земитис,

+37128369940; эл. почта: jurgis@iag.Iv

Юрис Сорокинс,

+37129969420;

эл. почта: juris.sorokins@gmail.com

Дарья Вадимовна Баранова,

+7(921)6401200; эл. почта: baranova-d@mail.ru

\section{Даниил Олегович Советников, +7(911)9019058; \\ эл. почта: sovetnikov.daniil@gmail.com}

